\title{
CROATIAN PRODUCED UNIFLORAL HONEYS CHARACTERISED ACCORDING TO THE PROTEIN AND PROLINE CONTENT AND ENZYME ACTIVITIES
}

\author{
Ivana Flanjak* \\ Ivica Strelec \\ Daniela Kenjerić \\ Ljiljana Primorac \\ Faculty of Food Technology, Osijek, Croatia \\ *corresponding author: ivana.flanjak@ptfos.hr \\ Received 18 June 2015; accepted 13 January 2016
}

Abstract

In honey, the content of proteins, including the enzymes, is relatively low and has a minor nutritive significance. On the other hand, the proteins, including the enzymes, are usually used as honey quality evaluation parameters. This is because protein content and enzyme activities vary regarding the botanical origin of the honey. Since the results of protein content, glucose-oxidase, and acid phosphatase, for honeys produced in Croatia, are not available, four of the most abundant honey types produced in Croatia (black locust, sage, chestnut, and honeydew honey) are characterised according to the protein and proline content and enzyme activities. The characterisation was done to determine specificities and contribute to the characterisation of unifloral honeys. Dark honey types (honeydew and chestnut honey) had a higher proline content, and diastase, invertase, and glucose-oxidase activity than lighter sage and black locust honey. Black locust honey has a naturally low enzyme activity and showed the highest acid phosphatase activity among the analysed honey types, while honeydew honey, otherwise known to possess high proline content and enzyme activity, had a low protein content comparable to black locust honey. Statistically significant correlations were obtained between all analysed parameters, with the exception of acid phosphatase activity.

Keywords: Croatia, enzyme activity, honey, proline content, protein content

\section{INTRODUCTION}

Honeybees produce honey from various floral sources and honeydew. Due to the differences in the chemical composition of the nectar and honeydew that the bees collect, the chemical composition of honey primarily depends on the botanical origin. However, climatic conditions and/or geographical origin can also have an effect on the chemical composition even within the same honey type (Anklam, 1998). Major honey components are carbohydrates (mainly monosaccharides, fructose, and glucose) and water. In small amounts, honey also contains minerals, proteins, phenolics, organic acids, volatile components, vitamins, and pigments. Although present in small amounts, these components are very important for honey characterisation and nutritive properties (White, 2000).

Honey contains up to $0.2 \%$ of proteins originat- ing mostly from the bees (Anklam, 1998). The protein content and composition in honey are often used for detection of adulteration (Won et al., 2008). Some honey proteins originate from nectar and pollen, and as such, are characteristic for certain honey types (Baroni et al., 2002). Several authors reported that a much better parameter for botanical and geographical origin identification, was the analysis of free amino acids in honey (Hermosín, Chicón \& Cabezudo, 2003; Cotte et al., 2004; Nozal et al., 2004; González Paramás et al., 2006). The major amino acid in honey is proline (80 - $90 \%$ of the total amino acids) with the exception of lavender, thyme, and rosemary honeys where the major amino acid is phenylalanine (Hermosín, Chicón \& Cabezudo, 2003; Cotte et al., 2004). The presence of proline is of animal origin and the quantity of proline depends on the time spent by the nectar in the bee's crop (Petrov, 1974). The proline content was proposed by the Inter- 
national Honey Commission as a honey ripeness and possible sugar adulteration indicator, with a minimum value of $180 \mathrm{mg} / \mathrm{kg}$ for fresh, genuine honey (Bogdanov et al., 1999). Besides proline, 26 amino acids (both essential and nonessential) were also identified in honey (Hermosín, Chicón \& Cabezudo, 2003).

Most of the proteins in honey are enzymes. Some enzymes present in honey come from nectar and/or pollen. Other enzymes are added by the bees during the transformation of nectar into honey, while only a small amount of the enzymes can originate from yeasts and bacteria present in the honey. Considering that enzymes are biological components sensitive to light, heat, and other energy sources (e.g. microwaves), the content and activity of enzymes in honey are generally used as a quality parameter and as an indicator of the processing and storage (White, 2000). However, different honey types show different enzyme activities. These activities, together with other parameters, can be used for the botanical origin identification. The most important honey enzymes are invertase, diastase, glucose-oxidase, catalase, and acid phosphatase. Invertase ( $\alpha$-glucosydase) coverts nectar sucrose to glucose and fructose, the key step in honey ripening, and catalyses transformations of other carbohydrates present in honey. The origin of invertase is attributed to the bee, although small amounts of invertase can be found in plants. Invertase continues its activity in honey even after extraction, slowly reducing the sucrose content. Variability in invertase content and activity as well as of other honey enzymes, is a result of several factors including abundance of nectar flow, nectar sugar content, temperature, diet and physiological stage of the bee, and strength of the colony (Persano Oddo, Piazza \& Pulcini, 1999). The high sucrose content in some honey types, like citrus, lavender or clover honey, results from heavy nectar flows or high-sugar nectars. Relatively little manipulation by the bees is needed to achieve honey density, consequently leading to low invertase activity in the above-mentioned honey types (White, 2000). Honey diastase is mostly present as $\alpha$-amylase which digests starch into simpler dextrines. Since honey does not include significant amounts of starch, the role of starch in honey has not yet been clearly stated (White, 2000; Babacan, Pivarnik \& Rand, 2002) although minor amounts of starch can be found in ripening honey (Balasubramanyam \& Ramesha, 2012). Although the origin of diastase is the bee, the activity of diastase varies depending on the honey type. Some unifloral honey (e.g. black locust and citrus honeys) and honeys from tropical regions have a naturally low diastase activity. Minimum values for the diastase activity of fresh and unprocessed honeys are given in international and national regulations (Codex Standard, 2001; Council Directive, 2002; Pravilnik o medu, 2009a). Glucose-oxidase is added to honey by the bees. The activity of glucose-oxidase is usually related to the honey antimicrobial properties. The enzyme catalyses the conversion of glucose to gluconolactone, which is further transformed to gluconic acid and hydrogen-peroxide $\left(\mathrm{H}_{2} \mathrm{O}_{2}\right)$. The resulting products are responsible for microbiological stability and prevention of the fermentation processes (Sheparts \& Subers, 1964). Honey also contains catalase which destroys hydrogen-peroxide, and therefore has the opposite role of glucose-oxidase. Honey contains acid phosphatase whose activity is related to the fermentation processes of honey. Acid phosphatase originates mainly from nectar and pollen and can be used as a parameter for honey characterisation (AlonsoTorre et al., 2006).

The aim of this study was to determine the protein and proline content as well as the enzyme activities of four honey types produced in Croatia: black locust (Robinia pseudoaccacia L.), sage (Salvia officinalis L.), chestnut (Castanea sativa Mill.), and honeydew honey. The data of protein content, glucose-oxidase, and acid phosphatase activity of Croatian honeys, to the best of the authors' knowledge, have not been reported yet. This means that the results of this study will contribute to the more complete characterisation of Croatian honeys. Additionally, the correlation between selected quality parameters was evaluated. 


\section{MATERIAL AND METHODS}

\section{Honey samples}

A total of 45 honey samples; 15 chestnut (C. sativa Mill.) and 10 samples of each: black locust ( $R$. pseudoaccaciaL.), sage (S. officinalis L.) and honeydew honey, were collected from Croatian beekeepers. The samples were stored at room temperature in the dark, and analysed within the month after extraction. To confirm the beekeeper's denomination, the samples were subjected to preliminary analyses. Uniflorality of samples was confirmed according to the method prescribed by the Louveaux, Maurizio \& Vorwohl (1978) while electrical conductivity and presence of honeydew elements was used to confirm the samples as honeydew honey. Samples were classified as black locust, sage, chestnut, and honeydew honey based on the analysis of parameters prescribed by the national and international regulations (Codex Standard, 2001; Council Directive, 2002; Pravilnik o medu, 2009a).

\section{Methods}

Protein content was determined by the spectrophotometric method (Bradford, 1976), based on the unspecific binding of the anionic form of Coomassie Brilliant Blue G-250 dye to basic and aromatic amino acid residues. The resulting blue protein-dye complex has maximum absorption at $595 \mathrm{~nm}$. The honey solution $(0.2 \mathrm{~g} / \mathrm{mL})$ was prepared in $50 \mathrm{mM}$ phosphate buffer ( $\mathrm{pH} \mathrm{7),}$ and $0.1 \mathrm{~mL}$ aliquot was mixed with $2 \mathrm{~mL}$ of Bradford reagent (Biorad, Germany). After a 5 minute incubation at room temperature, the absorbance was measured at $595 \mathrm{~nm}$ against the blank. The blank was prepared by mixing $0.1 \mathrm{~mL}$ of phosphate buffer (50 mM, pH 7) and $2 \mathrm{~mL}$ of Bradford reagent. The quantification was performed using bovine serum albumin (Sigma-Aldrich, USA) as the standard. The results were expressed as mg protein/100g honey.

Proline content was determined according to the AOAC Official Method 979.20 (AOAC International, 2002). Proline is the predominant amino acid in honey. It reacts with the acid ninhydrin solution and forms a coloured complex with a maximum absorption at $520 \mathrm{~nm}$. Interference from other amino acids is negligible; $\leq 5 \%$. The proline content in honey was quantified from the calibration curve using proline standard solution (Fluka, Germany) instead of honey. The results were expressed as mg proline/1000 g honey.

Invertase activity after Siegenthaler was determined according to the officially prescribed method (Bogdanov, Martin \& Lülmann, 1997). As a substrate for the determination of invertase activity in honey, $p$-nitrophenyl- $\alpha$-D-glucopyranoside (pNPG) was used. Invertase ( $\alpha$-glucosydase) present in honey splits pNPG (Sigma-Aldrich, USA) to glucose and $p$-nitrophenol. By adjusting the $\mathrm{pH}$ value of the reaction mixture at 9.5, the enzymatic reaction is stopped and nitrophenol is transformed to the nitrophenolate anion. The amount of nitrophenolate anion corresponds to the amount of converted substrate determined spectrophotometrically at $400 \mathrm{~nm}$, and the amount of $p$-nitrophenol $(\mu \mathrm{M})$ produced during the reaction is equal to the amount of utilised substrate $(\mu M)$. Therefore, honey invertase activity can be calculated from an absorbance measurement at $400 \mathrm{~nm}$, expressed as U/kg honey.

Diastase activity after Shade, was determined according to the officially prescribed method (Bogdanov, Martin \& Lülmann, 1997). The unit of diastase activity (Gothe unit) is defined as the amount of enzyme that will convert $0.01 \mathrm{~g}$ of starch to the prescribed end-point in $1 \mathrm{~h}$ at $40^{\circ} \mathrm{C}$ under the test conditions. Results are expressed in Gothe units (or Shade units) per gram of honey. A standard starch solution (Fluka, Germany), which forms a blue colour in a defined range of intensity when reacting with iodine, is acted upon by honey diastase under standard conditions. The decrease of blue intensity is measured at intervals. The time required for reaching an absorbance value of $0.235, t_{x^{\prime}}$ is calculated from absorbance/time diagram or a regression equation. The diastase activity is calculated as diastase number (DN) when 300 is divided by time $\left(\mathrm{t}_{\mathrm{x}}\right)$.

Glucose-oxidase activity was determined by the 
method of Schepartz \& Subers (1964). Glucoseoxidase catalyses oxidation of D-glucose to D-glucono- $\delta$-lactone and subsequent transformation to gluconic acid and hydrogen-peroxide
\& Grassl (1974). Acid phosphatase catalyses the reaction between $p$-nitrophenyl phosphate and water under the acidic conditions, creating the product with a maximum absorption at $405 \mathrm{~nm}$.

Medians, mean values, standard deviations and range for protein and proline content of analysed honey samples

\begin{tabular}{cccccc}
\hline Parameter & Statistics & $\begin{array}{c}\text { Black locust } \\
(\mathrm{n}=10)\end{array}$ & $\begin{array}{c}\text { Sage } \\
(\mathrm{n}=10)\end{array}$ & $\begin{array}{c}\text { Chestnut } \\
(\mathrm{n}=15)\end{array}$ & $\begin{array}{c}\text { Honeydew } \\
(\mathrm{n}=10)\end{array}$ \\
\hline Protein content & Median & $29.4^{\mathrm{a}}$ & $81.6^{\mathrm{b}, \mathrm{c}}$ & $96.2^{\mathrm{c}}$ & $57.6^{\mathrm{a}, \mathrm{b}}$ \\
{$[\mathrm{mg} / 100 \mathrm{~g}]$} & Mean \pm SD & $30.4 \pm 7.9$ & $79.2 \pm 13.9$ & $94.8 \pm 13.4$ & $59.4 \pm 21.8$ \\
& Range & $21.1-43.2$ & $53.5-104.2$ & $72.6-122.6$ & $30.0-95.3$ \\
Proline content & Median & $151.7^{\mathrm{a}}$ & $328.1^{\mathrm{a}, \mathrm{b}}$ & $679.9^{\mathrm{c}}$ & $430.0^{\mathrm{b}, \mathrm{c}}$ \\
{$[\mathrm{mg} / 1000 \mathrm{~g}]$} & Mean \pm SD & $157.0 \pm 21.5$ & $346.3 \pm 139.3$ & $699.0 \pm 142.9$ & $493.7 \pm 223.3$ \\
& Range & $127.1-200.7$ & $176.5-670.5$ & $390.9-916.4$ & $291.0-1005.8$ \\
\hline
\end{tabular}

Medians within a row sharing the same letter are not significantly different according to the Kruskal-Wallis test $(p<0.05)$

$\left(\mathrm{H}_{2} \mathrm{O}_{2}\right) . \mathrm{H}_{2} \mathrm{O}_{2}$ is reduced to water by peroxidase using $o$-dianisidine as a co-substrate. The formed coloured product has a maximum absorption at $400 \mathrm{~nm}$. The reaction mixture consisted of $0.7 \mathrm{ml}$ glucose $(2.14 \mathrm{mM}$, dissolved in $100 \mathrm{mM}$ sodium phosphate buffer, $\mathrm{pH} 6.1), 0.1 \mathrm{~mL}$ of ethanoic solution of $o$-dianisidine $(1 \mathrm{mg} / \mathrm{mL})$ (Merck, Germany), $0.1 \mathrm{~mL}$ peroxidase from horseradish (Serva, Germany) prepared in 100 mM sodium phosphate buffer, pH 6.1 (60 U), and $0.1 \mathrm{~mL}$ honey solution $(0.2 \mathrm{~g} / \mathrm{mL})$ prepared in $100 \mathrm{mM}$ sodium phosphate buffer (pH 6.1). After the addition of the honey solution, the reaction mixture was incubated for 30 minutes at $37^{\circ} \mathrm{C}$ and terminated by adding $0.1 \mathrm{~mL}$ of $1 \mathrm{M}$ hydrochloric acid. The absorbance of the mixture was measured at $400 \mathrm{~nm}$ against a blank which consisted of all the reaction components except honey. Measured absorbance was then corrected against the absorbance of the zero minute reaction mixture. The zero minute reaction mixture consisted of all the components, but the honey solution was added after the addition of hydrochloric acid. The quantification was performed using $\mathrm{H}_{2} \mathrm{O}_{2}$ as the standard (10-100 $\mu \mathrm{mol} / \mathrm{L})$ (Fluka, Germany) with peroxidase and o-dianisidine. The results were expressed as $\mu \mathrm{g}$ $\mathrm{H}_{2} \mathrm{O}_{2}$ /h g honey.

Acid phosphatase activity determination was performed as described by Bergmeyer, Gawehn
The reaction mixture consisted of $1 \mathrm{~mL} p$-nitrophenyl phosphate (Kemika, Croatia), with a concentration of $1 \mathrm{mg} / \mathrm{mL}$, prepared in $0.1 \mathrm{mM}$ sodium citrate buffer ( $\mathrm{pH} \mathrm{5.3)}$ and $0.1 \mathrm{~mL}$ honey solution $(0.2 \mathrm{~g} / \mathrm{mL})$ prepared in $0.1 \mathrm{mM}$ sodium citrate buffer ( $\mathrm{pH}$ 5.3). The reaction was started by the addition of the honey solution. After a 60 minute incubation period at $37^{\circ} \mathrm{C}$, the reaction was terminated by adding $2 \mathrm{~mL} 0.5 \mathrm{M}$ sodium hydroxide. The absorbance of the reaction mixture was measured at $405 \mathrm{~nm}$ against the $p$ nitrophenyl phosphate solution ( $1 \mathrm{mg} / \mathrm{mL})$ which was used as a blank. The measured absorbance was then corrected against the absorbance of the reaction mixture in zero minute. The zero minute reaction mixture consisted of all the components, but the honey solution was added after the addition of sodium hydroxide. The results of the acid phosphatase activity were expressed as mg P/100 g honey/24 h.

\section{Statistical analysis}

For each parameter mean value, the median and standard deviation were calculated and the range was given. Since the result values did not follow a normal distribution for all the parameters, the statistical evaluation of differences between honey types of the analysed parameters was tested by Kruskal-Wallis multiple comparison Z-value test. The relation- 
ship between the parameters was evaluated using Spearman's rank order correlation coefficient. The data analysis was performed using StatSoft, Inc. (2013).STATISTICA (data analysis software system), version 12. www.statsoft. com.

\section{RESULTS}

All collected honey samples were in compliance with national (Pravilnik o medu 2009a; Pravilnik o kakvoći uniflornog meda, 2009b) and international regulations (Codex Standard, 2001; Council Directive, 2002) regarding the melissopalynological analysis and prescribed physicochemical parameters. The specific pollen grain shares of $R$. pseudoacacia L. ranged from 22 up to $73 \%$. For the denomination of honey to be unifloral black locust honey, $20 \%$ is required (Pravilnik o kakvoći uniflornog meda, 2009b). Salvia officinalis L. pollen grains were from 11 up to $38 \%$, which ranged from 1.020 up to $1.594 \mathrm{mS} / \mathrm{cm}$, while the requirement is higher than $0.8 \mathrm{mS} / \mathrm{cm}$ (Codex Standard, 2001; Council Directive, 2002; Pravilnik o medu 2009a). Based on the results of preliminary analyses, the samples were classified as black locust, sage, chestnut, and honeydew honey. The protein and proline content of the analysed honey samples are noted in Table 1. Chestnut honey had the highest protein content (the mean was $94.8 \mathrm{mg} / 100 \mathrm{~g}$ ) followed by sage (the mean was $79.2 \mathrm{mg} / 100 \mathrm{~g}$ ), honeydew honey (the mean was $59.4 \mathrm{mg} / 100 \mathrm{~g}$ ). Black locust honey had the lowest protein content (the mean was $30.4 \mathrm{mg} / 100 \mathrm{~g}$ ). Black locust honey also had the lowest proline content with a mean of $157.0 \mathrm{mg} / 1000 \mathrm{~g}$. Chestnut honey had the highest proline content with a mean of $699.0 \mathrm{mg} / 1000 \mathrm{~g}$. The results of the enzyme activities are summarised in Table 2. Black locust honey had the lowest invertase (the mean was $52.1 \mathrm{U} / \mathrm{kg}$ ) and diastase activity

Table 2

Medians, mean values, standard deviations and range for enzyme activities of analysed honey samples

\begin{tabular}{|c|c|c|c|c|c|}
\hline Рагаmeter & Statistics & $\begin{array}{c}\text { Black locust } \\
(n=10)\end{array}$ & $\begin{array}{l}\text { Sage } \\
(n=10)\end{array}$ & $\begin{array}{c}\text { Chestnut } \\
(n=15)\end{array}$ & $\begin{array}{c}\text { Honeydew } \\
(n=10)\end{array}$ \\
\hline \multirow[t]{3}{*}{ Invertase activity [U/kg] } & Median & $40.9^{a}$ & $81.4^{\mathrm{a}, \mathrm{b}}$ & $158.6^{b, c}$ & $162.2^{c}$ \\
\hline & MeanะSD & $52.1 \pm 20.7$ & $94.7 \pm 52.1$ & $155.2 \pm 39.7$ & $176.1 \pm 48.9$ \\
\hline & Range & 28.4-91.2 & 26.4-199.5 & $90.5-219.6$ & 115.8-277.9 \\
\hline \multirow{3}{*}{$\begin{array}{c}\text { Diastase activity } \\
\text { [DN] }\end{array}$} & Median & $11.0^{\mathrm{a}}$ & $19.3^{\mathrm{b}}$ & $26.8^{\mathrm{b}}$ & $19.8^{\mathrm{b}}$ \\
\hline & Mean $\pm S D$ & $11.2 \pm 2.1$ & $19.9 \pm 6.8$ & $25.8 \pm 5.9$ & $21.7 \pm 8.4$ \\
\hline & Range & $7.5-13.9$ & $9.8-29.5$ & $16.9-35.5$ & $11.8-37.3$ \\
\hline \multirow{3}{*}{$\begin{array}{l}\text { Glucose-oxidase activity } \\
\qquad\left[\mu \mathrm{g}_{2} \mathrm{O}_{2} / \mathrm{h} \mathrm{g}\right]\end{array}$} & Median & $28.2^{\mathrm{a}}$ & $208.2^{\mathrm{b}}$ & $217.0^{\mathrm{b}}$ & $354.7^{b}$ \\
\hline & Mean \pm SD & $40.3 \pm 42.5$ & $250.5 \pm 122.9$ & $236.3 \pm 117.2$ & $347.6 \pm 55.7$ \\
\hline & Range & $1.5-144.0$ & $108.6-486.2$ & 105.1-517.9 & 253.7-431.6 \\
\hline \multirow{3}{*}{$\begin{array}{l}\text { Acid phosphatase } \\
\text { activity [mg P/100 g } \\
\text { honey/24 h] }\end{array}$} & Median & $100.0^{\mathrm{a}}$ & $38.4^{\mathrm{b}}$ & $82.2^{\mathrm{a}}$ & $82.7^{a}$ \\
\hline & Mean $\pm S D$ & $108.8 \pm 30.9$ & $43.3 \pm 16.7$ & $83.7 \pm 25.4$ & $137.1 \pm 118.4$ \\
\hline & Range & 81.5-179.1 & 20.9-79.2 & 35.7-127.3 & $53.4-406.8$ \\
\hline
\end{tabular}

Medians within a row sharing the same letter are not significantly different according to the Kruskal-Wallis test $(p<0.05)$

while the minimal requirement is $10 \%$ (Pravilnik o kakvoći uniflornog meda, 2009b). Unifloral chestnut honey denomination requires at least 85\% (Pravilnik o kakvoći uniflornog meda, 2009b) while our samples had from 85 to $98 \%$ of $C$. sativa Mill. pollen grains. Honeydew honeys were characterised based on the presence of honeydew elements and electrical conductivity (the mean was 11.2). The dark honey types; chestnut and honeydew honey, had the highest activities of the mentioned enzymes. Glucoseoxidase activity was the lowest for black locust honey (the mean was $40.3 \mu \mathrm{g} \mathrm{H}_{2} \mathrm{O}_{2} / \mathrm{h} \mathrm{g}$ honey), followed by sage (the mean was $250.5 \mu$ $\mathrm{H}_{2} \mathrm{O}_{2} / \mathrm{h} \mathrm{g}$ honey), chestnut (the mean was 236.3 $\mathrm{g}_{2} \mathrm{H}_{2}$ /h g honey), and honeydew honey 
(the mean was $347.6 \mu \mathrm{g} \mathrm{H}_{2} \mathrm{O}_{2} / \mathrm{h} \mathrm{g}$ honey). Acid phosphatase activity had an unusual ranking by honey type. Namely, sage honey had the lowest values of acid phosphatase activity with a mean value of $43.3 \mathrm{mg} \mathrm{P/100} \mathrm{g} \mathrm{honey/24} \mathrm{h,} \mathrm{followed}$ by chestnut (the mean was $83.7 \mathrm{mg} P / 100 \mathrm{~g}$ honey/24 h) and honeydew (the mean was $137.1 \mathrm{mg}$ P/100 g honey/24 h) while the black locust honey had highest mean value of 108.8 $\mathrm{mg}$ P/100 g honey/24 h. The Kruskal-Wallis test showed that black locust honey was significantly different from the other three analysed honey types as far as the diastase and glucose-oxidase activities were concerned. The Kruskal-Wallis test also showed that sage honey significantly differed from the other analysed honey types as far as the acid phosphatase activity was concerned. The other evaluated parameters were responsible for differentiation only between some honey types (Table 1 and 2).

Spearman's rank order correlation coefficients are summarised in Table 3. Statistically significant correlations were obtained between all analysed parameters, with the exception of acid phosphatase activity, which had not been significantly correlated with any of the analysed parameters. Protein content and glucose-oxidase activity showed the weakest correlation with Spearman's rank order correlation coefficient $0.439(p<0.05)$. The strongest correlation was obtained between protein-proline content and protein content-diastase activity with Spearman's rank order correlation coefficients $0.854(p<0.05)$ and $0.860(p<0.05)$, respectively.

\section{DISCUSSION}

Honey contains a small amount of proteins that originate from the bees and the nectarbearing plant. Generally, the data about honey protein content are very scarce and the results gained in this study are new for Croatian honeys. The protein content of Croatian black locust and honeydew honey are in compliance with the results for the same honey types from Romania whose protein contents were between 23.7 and $36.6 \mathrm{mg} / 100 \mathrm{~g}$ for black

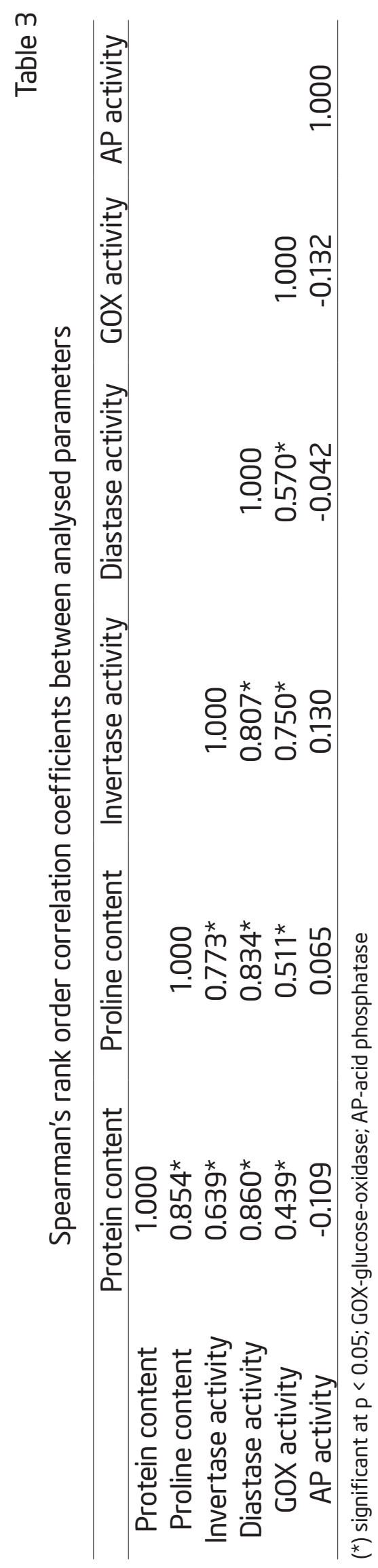


locust and between 37.1 and $76.3 \mathrm{mg} / 100 \mathrm{~g}$ for forest honey (Cimpoiu et al., 2013). Proline is a major honey amino acid and its presence in honey is of animal origin. The proline content is used as one of the criterions of honey ripeness and sometimes also as a sugar adulteration indicator. A proposed minimum proline value for the genuine honey was $180 \mathrm{mg} / \mathrm{kg}$ (Bogdanov et al., 1999) which was accepted by the majority of European beekeepers associations, as an additional quality parameter outside the standards. Black locust honey has a naturally low proline content which was also confirmed in this study, where only one sample had proline content higher than $180 \mathrm{mg} / \mathrm{kg}$. Comparing the results obtained in this study with the results for European unifloral honeys reported by the International Honey Commission (Persano Oddo \& Piro, 2004), our results for black locust honey were slightly lower than for the European black locust honey samples (112 - $337 \mathrm{mg} / \mathrm{kg})$. The proline content of other honey types analysed in this study was in compliance with our previously reported results for sage and honeydew honey (Kenjerić et al., 2006; Primorac et al., 2009) as well as with the proline content of the same honey type from different geographical regions (Cavrar et al., 2013; Rybak-Chmielewska et al., 2013).

The enzymes in honey mainly originate from the bee, but the enzyme activities of different honey types varies according to botanical origin. Most likely, the botanical origin is a result of the differences in the physiological stage of bees and the abundance of nectar flow during the season. The low enzyme activities of some honey types (e.g. black locust honey), is a result of a high nectar flow that does not allow the young bees to adequately process it. Honeydew honey has higher enzyme activities than nectar honey due to the fact that honeydew, collected and processed by the bees, is already rich with enzymes, especially invertase (Persano Oddo, Piazza \& Pulcini, 1999). Although enzyme activity varies depending on the botanical origin, it can be used as botanical origin criterion only for fresh honeys since enzyme activity decreases after processing and storing honey. Diastase and invertase activities are well documented for different honey types produced in Croatia and worldwide, but the data about honey glucose-oxidase and acid phosphatase activity for are scarce, and Croatian honey are not available in the literature. Diastase activity is usually used as an indicator of freshness and storage duration, and the minimum values for fresh, unprocessed honey are regulated. Yet, since diastase activity in some honeys (e.g. black locust, citrus, rosemary) is initially low, hydroxymethlyfurfural (HMF) content is included in their freshness evaluation. All analysed honey samples were in compliance with the regulations (Codex Standard, 2001; Council Directive, 2002; Pravilnik o medu, 2009a), which purports the fact that samples were fresh and properly handled (Table 2). The diastase activity determined in this study increased in this order: black locust<sage<honeydew<chestnut honey. The ranking was similar for invertase activity of analysed honey types, only honeydew honey had higher values of invertase activity than chestnut honey. Invertase activity is not prescribed as quality criterion in Croatian and international regulations, but some beekeepers associations (e.g. German, Spanish, and Belgian) use the invertase activity as an additional quality factor for determining the processing and storage conditions (Bogdanov et al., 1999). The invertase is more sensitive to high temperatures and storage conditions than diastase, and therefore, seems to be a more suitable parameter for the evaluation of honey freshness together with the hydroxymethylfurfural (HMF) content (Persano Oddo, Piazza \& Pulcini, 1999). The results of honeydew honey diastase and invertase activities obtained in this work, were slightly lower than those reported in our previous study where the median values were 25.4 and 208.7 U/kg, respectively (Primorac et al., 2009). The results for sage honey, though, were similar to the results reported in our previous study (Kenjerić et al., 2006). Diastase and invertase activities of chestnut honey obtained in this study are similar to the literature data (Persano Oddo, Piazza \& Pulcini, 1999; Persano Oddo \& Piro, 2004.). Glucose-oxidase catalyses degradation of glucose to gluconic acid and $\mathrm{H}_{2} \mathrm{O}_{2^{\prime}}$ and its activity in honey is related to the honey 
antimicrobial and antioxidant properties. Glucose-oxidase activity increased in the following order: black locust<sage<chestnut<honeydew honey. Acid phosphatase, unlike the former three analysed enzymes, has a plant origin. The activity of acid phosphatase increases with honey fermentation (Alonso-Torre et al., 2006). Unlike the other three analysed honey types which showed acid phosphatase activity inside a relatively small range, the results of honeydew honey acid phosphatase vary in a wide range from $53.4 \mathrm{mg}$ P/100 g honey/24 h to $406.8 \mathrm{mg}$ P/100 g honey/24 h (Table 2). This variation can be the result of differences between the origin of honeydew that the bees collect. Namely, the highest acid phosphatase activity $(406.8 \mathrm{mg}$ $\mathrm{P} / 100 \mathrm{~g}$ honey/24 h) was obtained in the sample from Italian oak (Quercus frainetto Ten.) which is produced in a specific way. Sweet sap with a foam-like appearance, is formed at the place where green acorns are discarded. Sweet sap is gathered by the bees and processed into dark honeydew honey. Considering that only a few studies available have evaluated the activities of glucose-oxidase and acid phosphatase, the comparison of obtained results is very limited. Sanchez et al. (2005) have reported the acid phosphatase activity of two chestnut samples as 71.8 and $67.6 \mathrm{mg} \mathrm{P} / 100 \mathrm{~g}$ honey/24 h, which were in the range of our results (35.7 - 127.3 $\mathrm{mg}$ P/100 g honey/24 h). The Kruskal-Wallis test was performed to evaluate the existence of differences for analysed parameters between honey types, and to identify where the differences occurred. Statistically significant correlations were determined between protein content, proline content, and analysed enzymes apart from the acid phosphatase activity (Table 3). The obtained correlations are to be expected since the presence of protein, proline, diastase, invertase, and glucose-oxidase in honey is mainly from the bees, while acid phosphatase is plant-derived. A high statistically significant correlation between diastase and invertase activity was also obtained in the study of Persano Oddo, Piazza \& Pulcini (1999) where the correlation coefficient was $0.835(p<0.05)$.

The studied unifloral honeys produced in Croatia are characterised according to the protein content and enzyme activities. The obtained results showed that protein and proline content as well as enzyme activities vary depending on the honey's botanical origin. The obtained results also showed that darker honey types generally had higher protein and proline contents and enzyme activities. Exceptions are the low protein content of honeydew honey and high acid phosphatase activity of black locust honey. The presented data contribute to the more complete characterisation of unifloral honeys since the results showing the protein content and activities of glucose-oxidase and acid phosphatase are new results for honeys produced in Croatia.

\section{REFERENCES}

Alonso-Torre, S. R., Cavia, M. M., Fernández-Muiño, M. A., Moreno, G., Huidobro,J. F., Sancho, M. T. (2006). Evolution of acid phosphatase acitivity of honeys from different climates. Food Chemistry, 97(4), 750-755. http://doi.org/1 0.1016/j.foodchem.2005.06.010

Anklam, E. (1 998). A review of the analytical methods to determine the geographical and botanical origin of honey. Food Chemistry, 63(4), 549-562. http://doi.org/10.1016/S0308-8146(98)00057-0 AOAC International (2002). AOAC Official Method 979.20 Proline in honey. In: Official methods of analysis. 17thed., rev.1, Ch 44. Gaithersburg, Maryland: 24.

Babacan, S., Pivarnik, L. F., \& Rand, A. G. (2002). Honey amylase activity and food starch degradation. Journal of Food Science: Food Chemistry and Toxicology, 67(5), 1625-1630. http://doi. org/10.1111/j.1365-2621.2002.tb08695.x

Balasubramanyam, M. V., \& Ramesha, I. (2012). Amylase and starch content in rippenin of honey of indigenous hive bee Apis cerana indica. Journal of Chemical, Biological and Physical Sciences, 2(1), 237-241.

Baroni, M. V., Chiabrando, G. A., Costa, C., Wunderlin, D. A. (2002). Assessment of the floral origin of honey by SDS-Page immunoblot techniques. Journal of Ag- 


\section{J. APIC. SOL. VOL. GO NO. 12016}

ricultural and Food Chemistry, 50(6), 1362-1367. http://doi.org/10.1021/jf011214i

Bergmeyer, H. U., Gawehn, K., \& Grassl, M. (1974). Enzymes as biochemical reagents. In: Methods of enzymatic analysis, vol. 1, 2nd ed. (pp. 495-496). Academic Press, Inc, New York.

Bogdanov, S., Martin, P., \& Lüllmann, C. (1997). Harmonised methods of the European Honey Commission. Apidologie (extra issue), 28, 1-59.

Bogdanov, S., Lüllmann, C., Martin, P., von der Ohe, W., Russmann, H., Vorwohl, G., Persano Oddo, L., Sabatini, A. G., Marcazzan, G. L., Piro, R., Flamini, C., Morlot, M., Lheretier, J., Borneck, R., Marioleas, P., Tsigouri, A., Kerkvliet, J., Ortiz, A., Ivanov, T., D’Arcy, B., Mossel, \& B., Vit, P. (1 999). Honey quality and International regulatory standards: review of the International Honey Commission." Bee world, 80(2), 61-69.

Bradford, M. M. (1976). A rapid and sensitive method for the quantitation of microgram quantities of protein utilising the principle of protein-dye binding. Analytical Biochemistry, 72, 248-254.

Cavrar, S., Yildiz, O., Sahin, H., Karahalil, F., \& Kolayli, S. (2013). Comparison of physical and biochemical characteristics of different quality of Turkish honey. UludağAricilik Dergisi, 73(2), 55-62.

Cimpoiu, C., Hosu, A., Miclaus, V., \& Puscas, A. (2013). Determination of the floral origin of some Romanian honeys on the basis of physical and biochemical properties. Spectrochimica Acta Part A: Molecular and Biomolecular Spectroscopy, 100, 149-154. http://doi.org/10.1016/j.saa.2012.04.008

Council Directive 2001/110/EC of 20 Decmber 2001 relating to honey. (2002) Official Journal of European Community L, 10,47-52.

Cotte, J. F., Casabianca, H., Giroud, B., Albert, M., Lheritier, J., \& Grenier-Loustalot, M. F. (2004). Characterisation of honey amino acid profiles using high-pressure liquid chromatography to control authenticity. Analytical and Bioanalytical Chemistry, 378(5). 1342-1350. http://doi.org/10.1007/

\section{s00216-003-2430-2}

González Paramás, A. M., Gómez Bárez, J. A., Cordón Marcos, C., García-Villanova, R. J., \& Sánchez Sánchez, J. (2006). HPLC-fluorimetric method for analysis of amino acids in products of the hive (honey and beepollen). Food Chemistry, 95(1), 148-156. http://doi. org/10.1016/j.foodchem.2005.02.008

Hermosín, l., Chicón, R. M., \& Cabezudo, M. D. (2003). Free amino acid composition and botanical origin of honey. Food Chemistry, 83(2), 263-268. http://doi. org/10.1016/S0308-8146(03)00089-X

Kenjerić, D., Primorac, Lj., Mandić, M. L., Bubalo, D., Perl Pirički, \& A., Flanjak, I. (2006). Dalmatian sage (Salvia officinalis L.) honey characterisation. Deutcshe Lebensmittel-Rundschau, 102(10), 479-484.

Louveaux, J., Maurizio, A., \& Vorwohl, G. (1978). Methods of melissopalynology. Bee World, 59, 139-157. Ministarstvo poljoprivrede, ribarstva i ruralnog razvoja: Pravilnik o medu [Regulation of the Ministry of Agriculture, Fisheries and Rural Development of Jul 31, 2009 refering to the detailed requirements of commercial quality of honey]. Narodne novine, 93/09, 2009a, 7-8.

Ministarstvo poljoprivrede, ribarstva i ruralnog razvoja: Pravilnik o kakvoći uniflornog meda [Regulation of the Ministry of Agriculture, Fisheries and Rural Development of Oct 12, 2009 refering to the detailed requirements of quality of unifloral honey]. Narodne novine, 122/09, 2009b, 15-16.

Nozal, M. J., Bernal, J. L., Toribio, M. L., Diego, J. C., \& Ruiz, A. (2004). Rapid and sensitive method for determining free amino acids in honey by gas chromatography with flame ionization or mass spectrometric detection. Journal of Chromatography $A$, 1047(1), 137-146. http://doi.org/10.1016/j.chroma.2004.07.013

Persano Oddo, L., \& Piro, R. (2004). Main European unifloral honeys: descriptive sheets. Apidologie, 35, s38-S81. http://doi.org/10.1051/apido:2004049

Persano Oddo, L., Piazza, M. G., \& Pulcini, P. (1 999). In- 
vertase activity in honey. Apidologie, 30(1), 57-65.

Petrov, V. (1974). Quantitative determination of amino acids in some Australian honeys. Journal of Apicultural Research, 13(1), 61-66. http://doi.org/1 0.1080/00218839.1974.11099760

Primorac, Lj., Angelkov, B., Mandić, M. L., Kenjerić, D., Nedeljko, M., Flanjak, l., Perl Pirički, A., \& Arapceska, M. (2009). Comparison of the Croatian and Macedonian honeydew honey. Journal of Central European Agriculture, 103), 263-270.

Revised Codex Standard for honey CODEX STAN 12-1981, Rev.1 (1987), Rev.2 (2001). Alinorm, 01/25, 19-26.

Rybak-Chmielewska, H., Szczęsna, T., Waś, E., Jaśkiewiez, K., \& Teper, D. (2013). Characteristics of Polish unifloral honeys IV. Honeydew honey, mainly Abies alba L. Journal of Apicultural Science, 57(1), 51-59. http://doi.org/10.2478/jas-2013-0006

Sánchez, M. P., Huidobro, J. F., Muniategui, S., \& Sancho, M. T. (2005). Evolution of acid phosphatase activity during the storage of honey. Deutcshe Lebensmittel-Rundschau, 107(1), 9-15.

Schepartz, A. I., \& Subers, M. H. (1 964). The glucose oxidase of honey. I.Purification and some general properties of the enzyme. Biochimica et biophysica acta, 85, 228-237.

StatSoft, Inc. (2013).STATISTICA (data analysis software system), version 12. www.statsoft.com. White, J. W. (2000) Honey. In: The Hive and the Honey Bee. (pp. 869-918). Illinois: Dadant\&Sons, Hamilton.

Won, S. R., Lee, D. C., Ko, S. H., Kim, J. W., \& Rhee, H. I. (2008). Honey major protein characterisation and its application to adulteration detection. Food Research International, 47, 952-956. http://doi. org/10.1016/j.foodres.2008.07.014 